\title{
Anthós
}

\section{Operatic Observation of the Audience: Examining Chapter One of Edith Wharton's The Age of Innocence}

Andréa René Franke

Portland State University

Follow this and additional works at: https://pdxscholar.library.pdx.edu/anthos

Part of the Comparative Literature Commons

Let us know how access to this document benefits you.

\section{Recommended Citation}

Franke, Andréa René (2013) "Operatic Observation of the Audience: Examining Chapter One of Edith Wharton's The Age of Innocence," Anthós: Vol. 5: Iss. 1, Article 4.

https://doi.org/10.15760/anthos.2013.33 


\section{Operatic Observation of the Audience: Examining Chapter One of Edith Wharton's The Age of Innocence}

Andréa René Franke

The act of observation, as defined by Professor Lawrence Wheeler's Fall 2012 Syllabus for his course titled “Theatron”, is “a morally complex act undertaken by qualified agents, operating through recognized and formalized practices, in a specific venue, and in possession of a carefully delimited vocabulary of discourse." Throughout many disciplines this formalized practice can be identified in many forms while still prescribing to this narrow definition. This essay will show how this definition of observation is applied to early 20th century American literature in Edith Wharton's The Age of Innocence (1920) by examining the first chapter of Wharton's museum cultured novel. Using the works of scholars interested in the American opera scene at the turn of the century and Wharton's portrayal of New York's elite, this essay will show how the first chapter's opera scene specifically applies to Wheeler's definition of observation.

In Edith Wharton's The Age of In nocence, the author brings the reader into an observational position of New York's elite lifestyle. Showcasing multiple practices of observation that intertwine at the opera -as upper class New Yorkers practically ignore Faust- the elite crowd observes and judges each other based on 1870s New York societal norms and expectations from their box seats. Rather than slowly weaning the reader into upper class New York's formalized practices, the author places the reader, as though in one of the box 
Anthós, Vol. V, Issue 1

seats reserved for only the most wealthy, in the specific venue of the Academy of Music Opera House. In John Dizikes's words from Opera in America: “[New York society's] attention focused on the Academy of Music, venerable by New York standards, a symbol of cultural refinement and social standing. The Academy was the hub of the social season and opera boxes were the center of the hub" (216). As the reader has been placed into New York's high society in the opening of her novel, as well as the opening of the opera season, Wharton makes sure the reader immediately begins to grow accustom to what is "the thing" (6) in New York and what is "not the thing" (6).

It is no mistake that Wharton chooses to commence her novel at the beginning of the opera season where elite New Yorkers can gaze upon each other from their respective box seats rather than watch the opera — which they have already missed half of since it is "the thing" to arrive late. In Maureen E. Montgomery's words from Displaying Women: Spectacles of Leisure in Edith Wharton's New York: "Attending the opera ... was a key social activity that helped define those who were members of the inner circle" (22). As this was the custom of this first opera night, the reader begins to observe who has been chosen to be part of the inner circle this season and who has not through the eyes of Newland Archer, the main character, who arrives fashionably late at the end of Act III when Marguerite and Faust have just finished singing "Tardi si fa Addio" (Wharton 18).

As it so happens, the script of the opera is only twenty-four pages long, and Archer, clearly finding more importance in his yearly observation of his fellow elites, arrives on page eighteen of the opera script already having missed more than half of the opera. But the opera itself is not what is important to the New Yorkers, it is the society that operas and other social gatherings help create and stabilize.

True to Dizikes's words, Archer sits in his opera box and immediately begins to observe and analyze who has acquired box seats this season. Beginning with Archer's arrival and introduction in 
the third paragraph of the first chapter, the opera itself will only be observed by Archer in four paragraphs out of the eighteen paragraphs that make up the first chapter, while observation of the audience and Archer's daydreaming will take up the rest.

As mentioned earlier, Archer arrives late to Faust, which is 'the thing' in this era of New York society. Not only was it 'the thing' to come late to the opera, but Faust was one of the most popular operas of the 1870s. In Opera in America, Dizikes discusses The Academy of Music and its popularity in the chapter "The Building of the Metropolitan Opera House” (214). It is clear that Archer is at the top of his society in New York as he is privileged enough to attain a box seat: "A box at the opera. It was the apple of discourse thrown among New York plutocrats. It inspired a social comedy of supply and demand" (Dizikes 214).

When he does arrive we find that the choice of opera and timing of his arrival by Wharton is no mistake as Madame Nilsson, the Swedish opera singer (1843-1921) is playing the role of Marguerite, singing “Tardi si fa Addio" (Gounod 18): "If he had timed his arrival in accord with the prima donna's stage-manager he could not have entered the Academy at a more significant moment than just as she was singing "He loves me-he loves me not-he loves me!" and sprinkling the falling daisy petals with notes as clear as dew" (6). The timing of his arrival is indeed significant; the lines being sung by Madame Nilsson are the lines Archer will repeat over and over in his head throughout the rest of the novel as he contemplates his engagement and later marriage to May Welland and his affair with Ellen Olenska well into his fifties. Thus this arrival of Archer into the opera and the book is important to note before examining the ways in which Archer and the other members of the audience observe one another in the first chapter of the novel.

The first observation that occurs takes place in the seventh paragraph of the novel and begins with Archer in one of the privileged club boxes, surrounded by his fellow elite, yet alone in his 
Anthós, Vol. V, Issue 1

thoughts: "Newland Archer, leaned against the wall at the back of the club box, turned his eyes from the stage and scanned the opposite side of the house" (Wharton 7). This is the first action by Archer that is described after his arrival to the opera box. Though the opera itself is mentioned, the explanation of the opera comes directly from the narrator rather than the narrator explaining Archer's thoughts and actions. This is the first act of observation that occurs in Wharton's novel.

By Archer leaning back and turning his gaze towards to opposite side of the house to examine the other club boxes he is engaging in a recognized and formalized social practice of upper class New York. Not only is he identifying with the upper class, he is also identifying with the role of the elite male in New York society. Montgomery discusses the role of the elite male which Archer embodies completely:

By appearing in public and displaying luxury, particularly in places of nighttime entertainment where conspicuous dress was allowed, the society woman took on the role of the courtesan in exhibiting herself as the possession of one man and evoking the envy of others-while display was concentrated on the sexualized body of the woman, spectatorship was predominantly male activity. (117)

During this chapter the concentration of the sexualized body of the woman is key. As the first chapter continues to be narrated by the omniscient third person, the fact that his observation is a formalized practice will become clear as the narrator describes the observations of the other elite attendees of Faust.

Continuing with this first observation, the details of the private secrets and lives of the other club box occupants are detailed to the reader, from why Mrs. Manson no longer attends the opera — which is rather private, though all of New York appears to know, about her "monstrous obesity" (3)—to private, sexual observations of the young 
women by Archer: “As Madame Nilsson's “M'ama!” thrilled out above the silent house ... a warm pink mounted to the girl's cheek, mantled her brow to the roots of her fair braids, and sufficed the young slope of her breast line to the line where it met a modest tulle tucker fastened with a single gardenia” (Wharton 7). Though Archer is engaged to be married to May Welland, another member of the New York elite circle, he still engages in the sensual observation of other females while ignoring the opera.

This particular observation of the new young lady at the opera is particularly important as it demonstrates the immediate lust and curiosity Archer feels for the unknown or new presence of someone he has never seen. After this brief satisfaction Archer returns his eyes to the stage but only to begin his own song of "[She] loves me-- [she] loves me not-[she] loves me!” (6), that Wharton frames perfectly using the script of the opera as a comparison to Archer's own life and feelings, as he daydreams not only about his fiancé, May Welland, but also the mysterious girl occupying the box across from him.

Some credit must be given to Archer and his limited observation of the opera, as it is clear that he has seen the opera many times before, and is thus familiar with the entire plot line and the extent of each character's role. Once Archer and the rest of the club box occupants have memorized the opera they turn their eyes towards each other to observe one another. The next observer after Archer is Lawrence Lefferts, and a different new mysterious girl has captured his attention: “'Well-upon my soul!’ exclaimed Lawrence Lefferts, turning his opera-glass abruptly away from the stage. Lawrence Lefferts was, on the whole, the foremost authority on 'form' in New York ... 'My God!' he said; and silently handed his glass to old Sillerton Jackson" (Wharton 9). At this moment it becomes clear that the presence of this new female is the center of the night at the opera as the alleged "authority on form" (Wharton 9) literally examines the new presence through an opera glass. 
Anthós, Vol. V, Issue 1

This female whom Lefferts has spotted is no stranger, but a member of New York's elite past returning after many years. This female character, Countess Ellen Olenska, becomes the center of attention and scandal for the rest of the novel, and is the person who comes between Archer and Welland's engagement and marriage. Unable to become part of New York's elite again, Archer finds himself first feeling pity for Olenska and then falling for her.

Lefferts, like Archer, appears to have little interest in the events taking place on the operatic stage and much prefers the sudden appearance of the familiar and scandalous figure given his reaction. As seen by the image of the antique opera glasses below, they are large enough so that if Olenska happened to glance up at Lefferts while he was looking at her, she would have noticed.

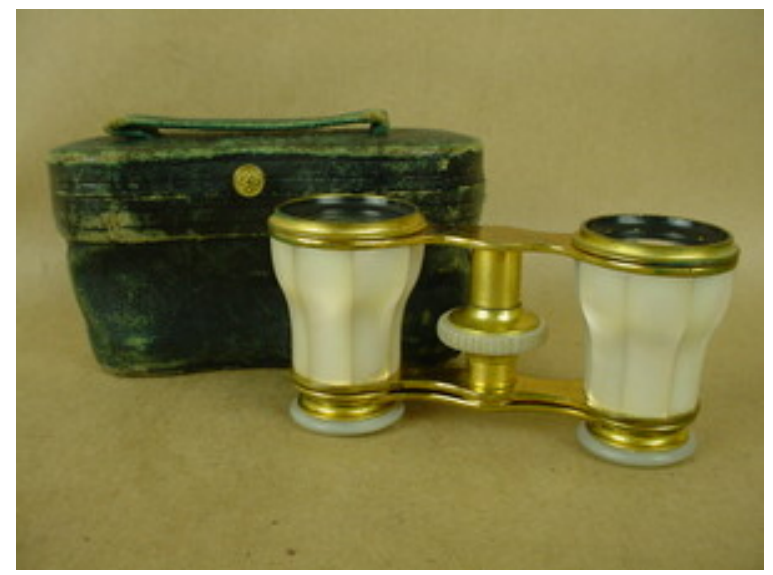

Figure 1. Opera Glasses, Chicago.

Anyone else who happened to look at Lefferts while he observed, including Archer, could have follow his gaze: "Newland Archer, following Lefferts's glance, saw with surprise that his exclamation had been occasioned by the entry of a new figure into old Mrs. Mingott's box" (Wharton 9). This is the first time that Archer, and the reader, view the glamorous but out of place character of Ellen Olenska: 
It was a slim young woman, a little less tall than May Welland, with brown hair growing in close curls about her temples and held in place by a narrow band of diamonds. The suggestion of this head-dress, which gave her what was then called a "Josephine look", was carried out in the cut of the dark blue velvet gown rather theatrically caught under her bosom by a girdle with a large old-fashioned clasp. The wearer of this unusual dress. . . . seemed quite unconscious of the attention it was attracting. (10)

After this second observation by Archer it is clear that his eyes are spent most in the audience rather than the play. Carmen Trammell Skaggs describes in her article "Looking through the Opera Glasses: Performance and Artifice in the Age of Inn ocence”, the social boundaries for being able to watch the women in the opera house instead of watching the opera itself:

This theatrical venue provided the stage not only for the musical and dramatic performance by the opera stars but also as the platform for a complex performance of class and gender relations. The spectacle of the women's opera boxes provided an opportunity to demonstrate the wealth and leisure of New York's upper class. Displayed in their evening dresses and jewels, the women embodied the wealth, refinery, and gentility of their stock. (50)

In the descriptions of the "gentility of their stock" (Skaggs 50) the description of Olenska contrasts that of the mysterious girl in the other club box. For one, Olenska's outfit is completely out of style. Knowing that this novel is set in 1870s and Empress Josephine, first wife of Napoleon Bonaparte, reigned in France from 1804 until Bonaparte divorced her in 1810, it is clear that from head to foot Olenska is not in rhythm with the latest fashion (see Figure 2). Words 
Anthós, Vol. V, Issue 1

such as "theatrical" and "old-fashioned" (Wharton 10) are used to describe Olenska's clothing, whereas words such as "modest”, "fair", and "warm" (Wharton 7) are used in contrast to describe the first young woman who captured Archer's attention. These two examinations of the 'costumes' worn by the audience are part of the observations that are happening between audience members.

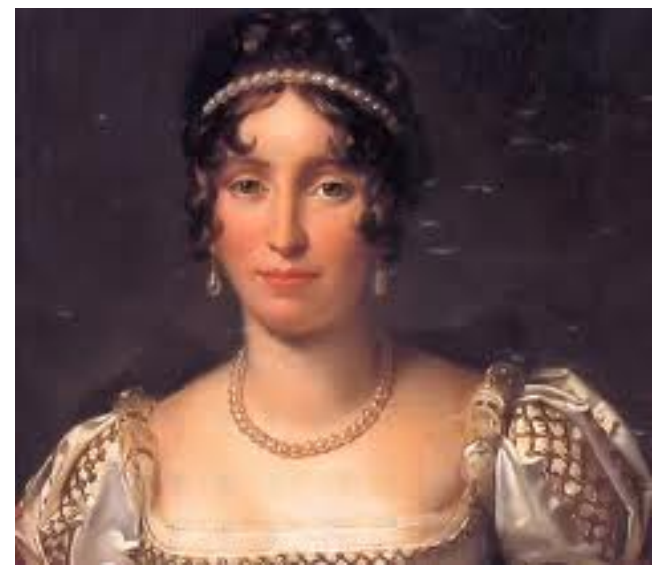

Figure 2. Empress Josephine.

Following these three observations - that of the young girl by Archer, Olenska's entrance by Lefferts, and Olenska's description by Archer-there comes the final observation of the first chapter which provides the most evidence that the entire club box audience is not paying attention to the opera. This observation occurs when Sillerton Jackson returns the opera-glass to Lawrence Lefferts: “The whole of the club turned instinctively, waiting to hear what the old man had to say, for old Mr. Jackson was as great an authority on 'family' as Laurence Lefferts was on 'form'” (Wharton 10). The suspense that is felt while the audience waits is absurdly clear as the people on the stage of the opera become the background and the actions and words of those in the club box seats become the most important occurrence for the New Yorkers: 
The club box, therefore, waited in visible suspense while Mr. Sillerton Jackson handed back Lawrence Lefferts's operaglass. For a moment he silently scrutinized the attentive group out of his filmy blue eyes overhung by old veined lids; then he gave his mustache a thoughtful twist, and said simply: 'I didn't think the Mingotts would have tried it on.

I have shown how Wheeler's definition of a formalized practice of observation can take place in the specific venue of the Academy of Music in 1870s New York. Each member of New York's elite is equally placed in society until they are either moved up or down the social ladder based on the observations of others; not only are the actions of each individual remembered and judged, the appearance of each person is part of their societal costume, so to speak. The final word on the normality and acceptability of each social action and presentation is given to the experts - in this case Lawrence Lefferts is the authority on form and Sillerton Jackson on family. If a member of Wharton's New York elite does not follow the recognized and formalized practices set by this specific venue, the rest of society will first judge them before leaving the absolute and final judgment to its experts, Lefferts and Jackson. In this presentation of the opera, the audience makes up the drama while the opera becomes the backdrop.

\section{Works Cited}

Dizikes, John. Opera in America: A Cultural History. New Haven, CT: Yale University Press, 1993. Print.

Gounod, Charles. Faust. Boston: Oliver Ditson Company, 1864. Print

Montgomery, Maureen E. Displaying Women: Spectacles of Leisure in Edith Wharton's New York. New York: Routledge, 1998. Print.

Skaggs, Carmen T. "Looking through the Opera Glasses: Performance and Artifice in the Age of Innocence." Mosaic 37.1 (2004): 49-59. Web.

Wharton, Edith. The Age of Innocence. New York: Barnes \& Nobel Classics, 1920. Print. 
Anthós, Vol. V, Issue 1

Wheeler, Lawrence. “Theatron.” Portland State University. Fall 2012. Syllabus. 